\title{
What is an appropriate measure of litigation? Quantification, qualification and differentiation of dispute resolution
}

OÑati SOCiO-Legal Series Volume 11, Issue 2 (2021), 320-353: “ToO Much Litigation?”: FACTS, REASONS, CONSEQUENCES, AND SOLUTIONS

DOI LINK: HTTPS://DOI.ORG/10.35295/OSLS.IISL/0000-0000-0000-1146

RECEIVED 02 SEPTEMBER 2019, ACCEPTED 24 FEBRUARY 2020

\section{CARRIE MENKEL-MEADOW*}

\section{Abstract}

This article reviews the claims about rates of litigation in the United States, as either "too much" or "too little" (e.g. "The Vanishing Trial"). While we need to understand aggregate litigation rates to assess access to justice, it may be more important to understand litigation rates in the context of differentiated case types. Litigation, in some cases, produces too "brittle" (binary) or costly outcomes, which is what led to the American " $\mathrm{A}$ " (alternative/appropriate) Dispute Resolution movement. This movement (now moving across the globe) may provide "process pluralism" with greater flexibility in outcome and cost variations, (now often called "a"ccesible dispute resolution"). However, litigation is still important in a variety of justice-seeking contexts (e.g. for new rights creation, old rights enforcement, and precedent elaboration). This article suggests that the question of how much litigation is appropriate in any legal culture is dependent on a variety of factors that goes beyond simple aggregate counting. The article concludes with a critique of recent American legal practices in restricting litigation through mandatory arbitration, non-disclosure agreements, class action limitations, privatized mass claim settlements, and restrictive jurisdictional interpretations in judicial decision making and legislation.

\section{Key words}

Litigation; ADR; process pluralism; access to justice

\footnotetext{
Thanks to Amy Cohen, Naomi Creutzfeldt, Jean Sternlight, brave Julie Macfarlane, and the attendees at the Oñati Workshop on Too Much Litigation? (June 27-28, 2019) and anonymous reviewers for useful comments. Special thanks to Eyal Katvan, Ulrike Schultz and Avrom Sherr and others in this effort, for organizing such a stimulating set of three workshops over many years on litigation, lawyers and judges in comparative perspective. And thanks to my assistant, John Arden for research assistance, and as always, Dianna Sahhar for library service par excellence.

* Distinguished Professor of Law and Political Science, University of California, Irvine and Chettle Professor of Dispute Resolution, Law and Civil Procedure, Emerita, Georgetown University. 401 E. Peltason Dr., Irvine, California USA 92697. Email address: cmeadow@law.uci.edu.
} 


\section{Resumen}

Este artículo repasa las afirmaciones de que hay "demasiados" o "demasiado pocos" litigios en los EE. UU. Si bien es necesario entender las proporciones de litigios agregados para evaluar el acceso a la justicia, tal vez sea más importante entender las proporciones de litigios en el contexto de tipos de casos diferenciados. En algunas ocasiones, los litigios producen resultados demasiado "frágiles" (binarios) o costosos, lo cual originó el movimiento llamado "American 'A' (alternativo/adecuado) Dispute Resolution". Este movimiento, ahora en expansión por todo el mundo, puede proporcionar "pluralismo procesal" de forma más flexible con diferentes resultados y costes (lo que ahora se denomina "resolución de conflictos 'a'ccesible"). Sin embargo, el acto de litigar sigue siendo importante en varios contextos de búsqueda de justicia (por ej., para crear nuevos derechos, para aplicación de viejos derechos, y para la elaboración precedente). Este artículo da a entender que la proporción de litigios apropiada en cualquier cultura jurídica depende de varios factores más allá de un recuento. Se concluye con una crítica de prácticas jurídicas recientes en América, consistentes en la restricción del litigio por arbitraje obligatorio, acuerdos de confidencialidad, limitaciones en demandas colectivas, liquidación de reclamaciones colectivas e interpretaciones jurisdiccionales restrictivas en la toma de decisiones judiciales y en la legislación.

\section{Palabras clave}

Litigio; Resolución Alternativa de Conflictos; pluralismo procesal; acceso a la justicia 


\section{Table of contents}

1. Introduction: competing narratives about litigation and its goals - Quantity or quality?

2. The quantitative claims: Too much litigation? Or not enough litigation?

3. The qualitative claims: Not the right kind of litigation/dispute resolution. 331

4. Differentiated claims: Variations in what we need litigation for 335

5. Policy implications.

References. 
Not everything that counts can be counted, and not everything that can be counted counts. (Albert Einstein)

\section{Introduction: competing narratives about litigation and its goals - Quantity or quality?}

Since at least the mid-1970's many commentators on the American legal system have proclaimed that there is too much litigation in the United States and Americans are far too litigious (Galanter 1983, 1986). From the Roscoe Pound (1976) Conference on the Popular Causes of Dissatisfaction with the Administration of Justice to Bayless Manning's (1977) worries about "Hyperlexis" as a "national disease", and Chief Justice Warren Burger's (1982) desires for "a better way" (outside of court) to deal with American disputes, to the claims of a "tort crisis" (Abel 1987, Saks 1992, 1993, Baker 2007) and overlarge and punitive jury awards (Hans and Vidmar 1986), commentators have decried the number of lawsuits filling both federal and state courts. This argument also often includes claims there are too many lawyers (see Katvan et al. 2017) resulting in an overpopulation of professionals willing to file almost any case (especially with the incentives of the American contingent fee, Kritzer 2004). As de Tocqueville first proclaimed, "the tendency of Americans [to] convert any issue of contest over political policy to a juridical and legalized question" for the courts to resolve (de Tocqueville 1835, Kagan 2001). ${ }^{1}$ Thus, as Robert Kagan has observed, Americans tend to convert both public and private disputes into an occasion for "adversarial legalism" and to use courts as a principal, if not the only, method for dispute resolution. This is an argument about the "quantification" of litigation - what are the numbers, why are there so many lawsuits, lawyers and disputants and how should litigation occurrences and rates be compared to other forms of dispute resolution (e.g. administrative or executive action, political and legislative processes, private negotiation, mediation, or other forms of dispute resolution)? What are the numbers of cases, in what courts? Have they increased over time? Why and with what effects on the legal system and the larger society?

In the 1980s another set of claims about the failures of the litigation system to solve problems, for both private disputes and public policy issues (desegregation, poverty, health and safety, social welfare, economic equity, education, etc.) resulted in a complicated legal and social movement (in which I was a founder, Menkel-Meadow 1984, 2000, 2016b) for "alternative forms of dispute resolution" and different forms of legal "problem-solving" (Menkel-Meadow et al. 2019), now more often called "appropriate" dispute resolution. The claims of this critique of the legal system were not only that there might be too much litigation, but that the quality of dispute resolution and decision making in courts might not be optimal or appropriate for all disputes. Court decisions are usually binary, "brittle," and focused on applying precedent and past solutions to present or future problems ("path dependence") that inhibit tailored, flexible and contingent solutions to complex problems and human relationships. I and others argued that taking (some) cases and matters out of the courts and processing disputes in other ways, including integrative negotiation, mediation, negotiated rule-

\footnotetext{
${ }^{1}$ For a recent example, see the efforts of a group of children to challenge American policy and governmental inaction on climate change by suing the federal government for "breach of right to life and liberty" in Juliana $v$ United States (dismissed for lack of standing) (9th Cir. Ct. of Appeals, Jan. 17, 2020, No. 18-36082; see Heinzerling 2019).
} 
making, consensus building, use of Ombuds and other hybridized processes (Susskind et al. 1999, Menkel-Meadow 2003, 2020, Alberstein 2015, Creutzfeldt 2018) would produce better quality solutions to disputes and conflicts and policy making for both parties and society.

The ADR movement is now decades old and has spread to many other countries (Steffek et al. 2013), with a variety of different motivations and goals - quantitative docket reduction, desires for smoother cross-border dispute resolution (European Directive on Cross-border Mediation, 2008, Nolan-Haley et al. 2019), and hopes for more consensual, creative, as well as efficient, decision making in matters ranging from family law, commercial law, discrimination law, employment and international law (e.g. international commercial arbitration, WTO procedures and state-investor dispute resolution). There have been many efforts to evaluate whether and how "A"DR has affected justice systems all over the world (Menkel-Meadow 2010, Steffek et al. 2013, Ali 2018 - whether to reduce caseloads (quantitative measures) or to improve or alter the qualitative processes and outcomes of dispute resolution. For me, this is the qualitative question in asking if there is too much litigation. What is the appropriate measure of how disputes, conflicts and policy decisions are best arrived at from a qualitative perspective. Is it a question for the parties in the dispute or legal issue (who "owns" a dispute? Christie 1977, Menkel-Meadow 1995b, Sternlight 2004, Glover 2017), and/or for those affected by any particular litigation (or other) process and outcome (other affected parties, the larger society?). A part of this research activity and one of the major "canons" of socio-legal work is the concept of procedural justice (Lind and Tyler 1988) - how disputants feel about the way they were treated in a particular process (voice, dignity, being heard) affects how they evaluate the outcomes and decisions they "receive," separate and apart from the outcomes (the "dignitary" interest in dispute resolution).

In the last two decades, there have been critiques of the turn away from courts at both the quantitative level (Galanter 2004, Resnik 2011, 2015) and the qualitative level (Genn 2009), with commentators asserting that in the United States only about $2 \%$ of civil cases come to trial and full adjudicative decision (and about the same in criminal justice with our extensive plea bargaining system), ${ }^{2}$ thereby reducing "public facing" lawmaking in a common law system (Fiss 1984, Luban 1995, Gilles 2016), and thus not providing enough public resolution of significant matters where all, not just the parties, can see how justice is being done. In addition, with the peculiarities and almost unique forms of "cram-down" (mandatory) arbitration in consumer, business and employment relations in the United States, (Sternlight 2002), repeatedly sustained by the US Supreme Court, many important cases are removed from the public sphere of courts to private and confidential arbitral tribunals (Sternlight 1996, 2012, 2019, Resnik 2015). This is a

2 Galanter's systematic study of "the vanishing trial" found that in the United States there was a decline from 1962 of $11.5 \%$ of all civil cases filed that went to trial to $1.8 \%$ in 2002 , with a $60 \%$ decline in the absolute number of trials from the mid-1980's to the early 2000s. These numbers also paralleled similar numbers in criminal courts and in trial rates in state courts generally. Galanter also found that case types had changed in the period he studied - from a preponderance of tort cases, the federal (declining) docket had a preponderance of civil rights cases in the later years of data collection (Galanter 2004). Any percentage measure of "trial rates," of course, must be compared to "filing rates". Filing of claims in different subject areas (e.g. civil rights, torts, class actions, social security, etc.) have fluctuated as well in the past decades, see Administrative Office of the Courts Annual Reports (for federal cases), the National Center of State Courts (for some, but not all, data on state court filings over time). 
qualitative argument about where justice should be done and who has access to where it is done and how (with what procedures, rules, participants and transparency).

This paper suggests that the question of how much litigation is "appropriate" is a complicated question for any society - it is quantitative (justice requires efficiency, affordable and physical access), qualitative (what kind of processes and outcomes are appropriate and fair for particular parties) and differentiated (different kinds of matters may require different kinds of dispute resolution). One size may not fit all, and litigation is not the only or best way to effectively resolve all disputes (Menkel-Meadow 2002, 2006a). While the United States is well known for its "propensity" to litigate in court, many other societies provide other forms of dispute resolution in state tribunals and administrative proceedings (e.g. specialized labour, benefits and other hearing fora should these be counted in assessments of litigation rates and access to justice?) In this paper I will illustrate the complexity of answering questions about the appropriateness of litigation by focusing on a variety of modern day (but historically constant) harms and disputes and how they are being treated in both litigation and non-litigation venues.

Perhaps surprisingly, for a founder of the ADR movement, I will claim here that in some areas there is not too much litigation - but too little, as mandatory arbitration, mass settlement of some civil cases, some with non-disclosure agreements and other legal policies (e.g. restrictions on class actions) have siphoned off, away from the public court system, whole classes of disputes (e.g. sexual harassment, abuse of children (e.g. Catholic Church pedophilia, Moran 2019), employment discrimination, securities violations (Alexander 2016, consumer actions) so they are hidden from public view and deprive both would-be litigants and the public a true sense of justice (see Burbank and Farhang 2017 - removal of claims by doctrinal court action and interpretation - and Edelman 2016 - removal of claims through internalization of grievance mechanisms in organizations and away from the courts). Furthermore, newer forms of dispute resolution, in the form of algorithmic decision making and ODR (online dispute resolution; Katsh and Rabinovich-Einy 2017, Cortés 2018) raise new questions about whether and how litigation will be affected, in both numbers (potentially more access to some kinds of dispute resolution, if not "justice"; Sternlight 2020a) and quality of dispute resolution (less tailored and fair solutions, Menkel-Meadow 2018). The question of whether there is "too much or too little litigation" is really a question about what are the most appropriate ways to get to justice - for aggrieved parties and for larger societies. Finally, although this paper does not directly deal with the current larger political climate in the United States, litigation has been a necessary process to challenge the often unconstitutional, ultra vires, and immoral policies of the Trump administration (particularly in racist actions with respect to immigration, the census and roll backs of civil rights, environmental and other laws and regulations of long duration). ${ }^{3}$

\footnotetext{
3 See e.g. Hawaii $v$ Trump, 878 F. $3^{\text {rd }} 662$ (9 $9^{\text {th }}$ Cir. 2017) (affirming injunction against banning of relative immigration for banned Muslim nationalities); Dept. of Commerce v New York, 588 U.S. -(2019) (affirming injunction against adding citizenship question to U.S. Census); E. Bay Sanctuary Covenant v Barr, -F. Supp. $3^{\text {rd }} 2019$ WL 3323095 (N.D. Cal. 2019) (granting preliminary injunction nationwide preventing enforcement of an interim final rule categorically denying asylum) - by the time of publication, some of these will be overruled and there will be many more challenges to Trump actions in a variety of domains.
} 
Or, to put it another way, what is the purpose of litigation and courts (Shapiro 1981)? Justice? Dispute resolution? Rights creation and enforcement (Scheingold 1974, Rosenberg 2008)? Political expression (Lahav 2006)? Redress and remedies? For whom is a litigation system designed (its users, the people) or the public (and state, for transparent legal and political decision-making) (Menkel-Meadow 1995b). Are courts the only or best places to achieve "justice"? Has ADR privatized and moved too many cases away from public scrutiny, shielding particular actors and organizations from public accountability? Or, are some forms of "non-litigation" processes better for some people and some case types (more flexible, individualized solutions, some confidentiality and privacy in some settings) and who should be able to make what choices about appropriate fora for dispute resolution?

\section{The quantitative claims: Too much litigation? Or not enough litigation?}

Whether one thinks that there is too much litigation and reliance on law in American society (Howard 1994) or too little (Abel 1987, Engel 2016), there have been various efforts to measure the number of lawsuits over time and to calculate a variety of litigation rates historically, where possible by state, federal system and by subject area (see e.g. Morton Horowitz' study of US tort system historically; Horowitz 1977, 1992). During the 1976 Pound conference on the Causes of Popular Dissatisfaction with Justice (Sander $1976,111)$ a variety of scholars and judges presented data to argue that the federal courts were receiving vastly increasing numbers of cases making time to decision (trial courts some close to five years) and resolution to final appeal increasingly lengthy (sometimes close to 10 years for resolution). The mass influx of cases (many from newly won rights in civil rights, consumer, environmental and other regulatory statutory programs of the 1960s and 1970s) challenged the promises, in the Federal Rules of Civil Procedure, for "just, speedy and inexpensive determination of every action and proceeding" (Fed.R.Civ.P. 1(1)). Arguments were made by judges that increasing numbers of cases threatened time to decision, cost of litigation and also the quality of judgments reached. One judge famously suggested that federal law in the United States would become a "Tower of Babel" in which so many conflicting decisions in the federal system would result in too many contradictory cases and rules (made in a common law interpretative system). ${ }^{4}$

\footnotetext{
${ }^{4}$ I actually experienced this as a litigator when I moved from the US east coast (Philadelphia) to the west coast (Los Angeles) and found different lines of precedent in several areas in which I practiced (social security disability law, employment discrimination and prisoner's civil rights). For those unfamiliar with the American legal system - there are 94 federal district (trial) courts and 13 federal courts of appeals. The US Supreme Court has discretionary jurisdiction in most matters and will sometimes, but not always, accept an appeal where there is a "conflict in the circuits (courts of appeals)". And, there are 51 state court systems (50 states and the District of Columbia) with jurisdiction over state civil and criminal matters in all cases where the US Constitution "reserves" legislative power to the states. The federal government and Congress have only "enumerated" (specified) powers and jurisdiction. Thus, American law and legal precedent is by nature a "Tower of Babel" where, without pre-emption of a Supreme Court ruling or federal statute, there may be many different precedents at different levels of decision. The American legal federal system is, by its structure, inherently a system of legal pluralism. Other nations, of course, are also plural (with states or provinces with parallel legal authority) or "mixed" systems of both civil and common law (e.g., Canada, Scotland, Israel) so total clarity of a single legal system speaking with one voice is not necessarily the norm of formal adjudication in many parts of the world.
} 
In the late 1970s, using the data advancing the argument that civil filings had increased exponentially, several academics and judges urged a variety of strategies to reduce civil filings in the courts. Harvard Professor Frank Sander famously urged the creation of the "Multi-Door Courthouse" (Sander 1976) so that disputants could be assigned (depending on case type) to "varieties" of different kinds of dispute resolution (negotiation, mediation, conciliation, fact-finding, ombuds, arbitration, administrative hearings or other processes) in order to "reduce the judicial caseload." Note that this famous speech, then article, widely credited with ushering in the American ADR movement, was initially based on the "quantitative" argument - help judges get cases out of the courts. Later, both Sander and others (including myself) urged consideration of "appropriate" forms of dispute resolution for other purposes (see below - more qualitative reasons of different kinds of outcomes and processes, e.g. more party participation and more future focused, tailored solutions to legal problems). Then Chief Justice Warren Burger urged that using out of court processes was a "better way" to resolve disputes in many matters. Although framed as a "warmer way" of disputing, Burger's concerns were, in fact, quantitative - he wanted fewer cases in the Supreme Court and other federal court dockets. Burger's rhetoric at the Pound conference in fact ushered in an era of Supreme Court deflection and reduction of federal court jurisdiction which included broad interpretations of the pre-emptive value of the Federal Arbitration Act (1925), allowing removal to private arbitration of virtually all employment, consumer and even statutory claims when arbitration was specified in a contract (Mitsubishi v Solar, 1988 [anti-trust], Gilmer v Interstate/Johnson Lane Corp., 1991, Circuit City Stores v Adams, 2001 [employment], American Express v Italian Colors Restaurant, 2013, ATET Mobility v Concepcion, 2011 [consumer], etc.), and later "retrenchment" of federal jurisdiction in a variety of other civil rights, environmental and federal rights cases (Burbank and Farhang 2017), as well as constriction of class action remedies in federal court in a variety of different areas (Resnik 2011, Wal-Mart v Dukes, 2011, ATET Mobility $v$ Concepcion, 2011, Epic Systems Corp. v Lewis, 2018).

The politicization of data on the number of cases filed in the United States (in both federal and state courts) is almost as old as the court systems themselves. As historian Morton Horowitz documented, the increased use of courts in the beginning of the industrial age to use the tort system to try to recover for many new forms of harm (railroad, factory and ultimately automobile accident injuries), was met by powerful defendants and the "new" railroad lawyers who developed doctrines to limit the liability of the new corporations. Similarly, legal doctrine was also a battleground in the development and restrictions of organized labor in the late $19^{\text {th }}$ century, where courts and litigation were used by both sides of the labor struggle to seek recognition of or restrictions on collective action (Forbath 1991).

Both the Republican 19th century Progressive era of Theodore Roosevelt (anti-trust) and the New Deal of the Democratic era (Franklin Roosevelt - cousins!), during the Depression and World War II (social welfare) produced vast new numbers of statutes and ultimately the "administrative state" of thousands of regulations administered by both courts and the new "alphabet" agencies of the Executive Branch. These new and varied statutes governing such diverse matters as transportation, social security, communications, worker health and safety, securities, consumers, labor, commerce, education and eventually energy and the environment, created enormously complex 
frameworks of claims and enforcement. In some cases, enforcement and litigation were limited to the statutorily created agency (e.g. the National Labor Relations Board for union and collective bargaining issues). In other cases, the new statutes created a "private right of action" (Farhang 2010) which enabled private citizens to sue directly in court for violations of federal (or state) statutes (e.g. employment discrimination has its Equal Employment Opportunity Commission, but for most of its history, employment discrimination has been handled by private lawsuits). ${ }^{5}$ Some matters, e.g. anti-trust and securities could, in fact, be handled with parallel public (agency enforcement actions) and private causes of action, some with the possibility of treble or punitive damages. In the active period of the Democratic administrations of the 1960s (Lyndon Johnson after John Kennedy's assassination), many new laws, civil rights, consumer rights, environmental laws and new forms of administrative regulations did increase the number of court filings. (Administrative Office of the Courts, Annual Reports).

Separate from public litigation about new claims of rights, the insurance industry successfully captured the media with accounts of large punitive damages cases (the famous McDonald's Hot Coffee case) ${ }^{6}$ ushering in a media (and legislative) campaign to limit tort claims and recoveries. ${ }^{7}$ Much of this culminated in President Reagan's campaign in the 1980s to cut back on the legislative and judicial victories of the civil rights, consumer, feminist and labor movements. Broad claims of "too much litigation" destroying the "innovative spirit" of American capitalism became a rallying cry for the new Republican administration. Politicians made broad claims, but more scholarly researchers who closely examined the actual data (Galanter 1983, 1986, 2004, Hans and Vidmar 1986, Abel 1987, Saks 1992, 1993, Engel 2016, Burbank and Farhang 2017) documented that the "quantitative" story was far more complicated and in many areas (e.g. medical malpractice) there was actually much underclaiming.

Separating the politics from the measurement issues is no easy task. While many scholars documented that rather than too much, there was and is, in fact, underclaiming, in torts (Abel 1987, Saks 1992), medical malpractice (Saks 1993, Baker 2007), employment (Edelman 2016), consumer (Merry 1990, Engel 2016) or litigation in general (Galanter 2004), such arguments depend on what is considered a "frameable" legal claim (Felstiner et al. 1980-81) that can actually be made in a court. Socio-legal scholars have long studied claiming patterns (Miller and Sarat 1980-81) and legal needs (Sandefur 2014) to determine whether, in fact, citizens have access to justice and can actually claim (in a lawsuit or otherwise) for various perceived harms and wrongs. Most of these studies suggest that there is underclaiming due to costs of lawyers, litigation fees, lack of knowledge about legal rights and use of "others" to assist with what are not always

\footnotetext{
${ }^{5}$ This was actually done intentionally in the drafting of Title VII of the 1964 Civil Rights Act. The Republican members of the Congress did not want to empower a federal agency (the EEOC) with the same remedial powers as the NLRB.

${ }^{6}$ A verdict of punitive damages (over $\$ 2$ million, later reduced to $\$ 670,000$ ) made this one of the largest jury verdicts, "all for a cup of coffee!" In fact, the litigation is far more complicated. McDonald's was on notice about prior instances of coffee burns and the coffee at issue in the case was in fact served at 180-190 degrees, and resulted in eight days of hospitalization for the 79-year-old victim of spilled coffee, who required skin grafts; see Liebeck v McDonalds, 1995 WL 360309 (Dist. Ct. N. Mex.). The case became a cause celebre in the tort reform debates and HBO made a documentary about tort reform, HOT COFFEE! (2011).

7 BMW of North American, Inc. $v$ Gore, 517 U.S. 559 (1996) (overturning punitive damage award as excessive under substantive Due Process (14 ${ }^{\text {th }}$ amendment) analysis).
} 
considered to be "legal" problems (Menkel-Meadow 1979, Sandefur 2014, 2016). In recent years, the numbers of cases that are brought by pro se (not represented by lawyers) claimants has increased dramatically, in the United States, as elsewhere.

Rigorous empirical studies of claiming in a variety of areas (Nelson and Nielsen 2005, for employment; Edelman 2016, Burbank and Farhang 2017, for private actions for regulatory matters; Abel, Saks and Kritzer for torts) have demonstrated that in fact, concerted efforts to dampen and decrease litigation has been a political issue since the "rights revolution" of the 1960s and 1970s. Stephen Burbank and Sean Farhang's Rights and Retrenchment: The Counterrevolution against Federal Litigation (2017) systematically documents the efforts of Republican reformers to attempt to cut back federal statutes granting rights and private causes of action in civil rights, prisoner rights, securities litigation, anti-trust, employment and consumer rights. With Democratic Congresses during much of the Republican presidencies, formal statutory change was generally unsuccessful, except in a few areas, particularly in cutbacks to securities and prisoner rights class actions (see Schlanger 2004). Instead, what Burbank and Farhang demonstrate is that, with far more subtlety, and without the same public attention as Congressional politics achieves, legal reformers and their lawyers (from the right, Southworth 2008) have been able to cut back on federal rights claiming litigation by use of common law doctrinal development in the courts, using such doctrines as standing, class action certification requirements, attorneys fees decisions, pleading requirements and domination of the federal Advisory Committee for Civil Rules (the body which has control over the drafting and approval of federal rules of civil procedure (MenkelMeadow and Garth 2010).

Lauren Edelman (2016) and Robert Nelson and Laura Nielsen (2005) have documented other strategies used to tamp down employment discrimination claims, including the "internalization" of claiming within organizations, which then use their internal training and grievance systems as grounds for legal dismissal or mitigation in lawsuits. Thus, the true "measure" of possible claims that could be made is a complex product of both legal doctrinal developments (e.g. standing to sue, class action rules) and socio-legal issues of access to justice and lawyers, naming and framing of claims and clever institutionalization strategies of those who seek to limit litigation, deploying a variety of both legal and non-legal (socio-legal and political) techniques and strategies.

However, we construct denominators of possible claims that could be made, the numbers of claims in any measure of numerators has clearly been decreasing in the United States. In 2004 at a special symposium hosted by the American Bar Association on The Vanishing Trial a number of scholars systematically demonstrated that the occurrence of trials in civil courts has decreased (as a percentage of filed cases) to less than $2 \%$ of all filed civil cases, in virtually all categories of cases (Galanter 2004). While many cases are still "adjudicated," through some kind of summary proceeding, "on the merits" (Kritzer 1986), it is clear that civil trial (and criminal trial, rather than plea bargaining) is now the "alternative" form of dispute resolution in the United States.

Causes for this development are many. First, a now repealed law (in states like California) of "three strikes and you' re out" (meaning third criminal convictions resulted in life sentences) increased the number of criminal trials, making access to civil courtrooms, in some jurisdictions, very difficult. Second, a large proportion of filed cases 
have always been settled through negotiations, prior to trial. This number is now enhanced by Third, both in-court and out of court referrals to and use of "ADR". Both Federal Rules (Rule 16) and statutes (Civil Justice Reform Act 1990) now mandate the use of some settlement process before a trial in federal court, and most state courts also have such mandatory or strongly recommended ADR pre-requisites to trial ${ }^{8}$ (MenkelMeadow 2013). Fourth, as demonstrated in the access to justice studies noted above, there are many impediments to the use of courts by ordinary people (e.g., "framing" of a problem as a legal matter [Menkel-Meadow 1979 and Sandefur 2014]); costs and fees, access to lawyers and physical accessibility to a court). Fifth, in some matters, mass torts and mass claims, a new form of mass settlement through claims facilities and class action settlements (Rule 23e) (see, e.g., Sept 11 Victims Compensation Fund, Deepwater Horizon Oil Spill, Catholic Church claims fund [Elie 2019], product liability and disasters), have removed cases from the courts, both after filing and before filing, but before any individualized adjudication. This new form of systemic dispute resolution has advantages (relative speed of recovery) and disadvantages, now hotly debated among civil justice scholars (Menkel-Meadow 2009, Resnik 2011, 2015, Moran 2019). Finally, as I review in section 4 below (the major thrust of my argument in this paper), the massive use of mandatory arbitration clauses, approved by the US Supreme Court, coupled with both modern class action jurisprudence and the use of Non-disclosure Agreements (NDAs or "secrecy agreements", Menkel-Meadow 1993) in settling cases has removed and blocked a wide variety of cases from seeing the light of day in public litigation fora.

In my view, the numbers of litigated cases is an important but not dispositive issue on the question of whether there is an appropriate amount of litigation in any society. If valid claims are suppressed (as I argue they now are in the United States in some areas, see section 4) that is an issue for legal justice and democracy, no matter how small the number. If the number of litigated claims decreases because non-court processes or institutions provide "better" more tailored solutions to legal claims and issues (see section 3 below) then I am less worried, though we might still worry about how parties assess what is a "better" solution. ${ }^{9}$ If there is systematic absence of classes of cases that might be necessary for legal precedent development (Fiss 1984, Luban 1995), then I worry about that. That is perhaps less of a problem in civil law systems than in common law systems, like the US, where law is often made incrementally, through fact variation and differentiation and "policy" analysis by judges, as well as by legislators. If litigation is so plentiful that it is the only way citizens with disputes relate to each other (a really litigious society!) I worry about that as creating a largely adversarial and disputatious culture (Tannen 1998). Courts, as I have argued repeatedly (Menkel-Meadow 1984) have "limited remedial imaginations" and very rigid permitted outcomes (monetary relief, backward facing liability judgments and only occasionally forward-facing outcomes

\footnotetext{
${ }^{8}$ New York State has recently developed a policy that all civil cases will be presumptively referred to mediation (with some opt-out policies).

${ }^{9}$ When I was a consultant for the World Bank on their internal dispute resolution system, an economistengineer who was quantitatively focused thought it was a good sign that claims and grievances inside the WB's elaborate internal dispute system had declined in a particular period. What I learned through qualitative interviews was that the large staff, in a time of retrenchment, were fearful of making claims (especially with little retaliation protection in the internal rules of the WB). So, numbers are never the whole story in analyzing disputing practices and justice.
} 
(limited positive injunctions). Courts are not an ideal way for people to resolve all their differences or governments to set policy.

If, on the other hand, large institutions or powerful individuals can escape accountability, transparency and compensation (see Catholic Church pedophile crisis [Moran 2019] or Harvey Weinstein, film producer, repeated sex harassment [Farrow 2019, Kantor and Twohey 2019], or big Pharma opioid producers [Zimmer 2019]) with secret settlements, side payments or corruption, then I worry that we do not have enough of the right kind of litigation (or other processes) to assure public accountability, just compensation, and punishment for wrongdoers. We need to study the rates and numbers of litigation in any society to monitor access to justice, but it is far more important to look at the qualitative data and variations about what claims are being made, in what fields, and how they are being handled in any society. It is not only the numbers, but the kinds, of disputes, and the remedies that litigation can or cannot provide that we should be measuring, while asking what is the purpose of litigation in a particular legal domain or culture.

\section{The qualitative claims: Not the right kind of litigation/dispute resolution}

When the "litigation crisis" was "declared" in the United States in the 1970s (as increasing claims from the new civil rights and consumer rights legislation mounted), it was characterized by many as a "problem" of "too many cases" affecting the efficiency and efficacy of the litigation system. Or, big business and law and economics scholars argued that it was a mal-distributive device in allowing large jury verdicts to stunt economic growth and industrial creativity by "wasting" money on legal costs.

Just after the Pound conference in 1976 a group of us (Fisher and Ury in Getting to Yes [1982/2011], me in Toward Another View of Legal Negotiation [Menkel-Meadow 1984]) took another tack in the "too much litigation" claims. For us, it was not the number of cases but the quality of litigation processes and the outcomes they produced in particular matters. This was another take on the civil justice and access to justice movements of the 1960s and 1970s. For me, as recounted in many of my articles, coming from a poverty law practice, so many of the cases we "won" in court (summary judgments against governmental agencies for statutory and constitutional failures of due process) did not actually "solve" the underlying problem (e.g. bad prison conditions, unfair welfare systems, inadequate schools, discrimination claims, predatory banking procedures, housing scarcity, environmental disasters). I argued against the binary, brittle and pastfacing (precedent) outcomes of court outcomes, that also "shadowed" and influenced negotiated processes parallel to courts (Mnookin and Kornhauser 1979 - legal rules as limiting "bargaining endowments" in negotiations).

Roger Fisher, a veteran of World II, and an experienced Supreme Court advocate before becoming a Harvard law professor, was deeply affected by needless death and binary win-lose outcomes in court. In an intellectual convergence on both coasts (I like to think like the intellectual convergence around DNA discovery and AIDS research - scientists working on the same problem in different regions simultaneously), we suggested that there were "better" ways to resolve disputes than binary litigation (integrative, not distributive, negotiation and mediation) in which legal solutions were not the only possibility (Menkel-Meadow 2006b). Parties could participate more fully in framing 
future oriented, Pareto optimal (gains without unnecessary harms) solutions to their particular issues, seeking creative ("out of the legal box", Menkel-Meadow 2001) and resource expanding, rather than divided distributive, outcomes, by tailoring decisions and sharing information outside of the stylized form of contested adversarial evidentiary presentations in court (Menkel-Meadow 1996). These arguments for better qualitative dispute resolution were applied to many legal domains, as well as to political, policy and international dispute settlement.

One of the first ADR organizations to be founded in the United States (1979) (full disclosure: on whose executive board I sat for many years), the Center for Public Resources (CPR), championed the use of arbitration, mediation, and new hybrid dispute resolution processes - the private mini-trial, the public summary jury trial, med-arb, arbmed, ${ }^{10}$ and even private juries (Menkel-Meadow et al. 2019) - in order to promote more "effective and efficient" dispute resolution by processes outside of court. CPR asked General Counsel of the Fortune 500 businesses and eventually all major US law firms to sign a "CPR Pledge" to promise to use some form of ADR before and during expensive legal proceedings. Although virtually all of the major law firms represented Big Law, and therefore defendants (often big companies with disputes against each other or their insurers), CPR also played an important role in facilitating mass tort settlements (asbestos, Hyatt hotel ceiling collapse, Met Life insurance claims) which ultimately benefited some injured plaintiffs as well. Though the claim was primarily monetary saving litigation costs - CPR eventually also became a think tank and "host" of the other side of the ADR movement - the "qualitative" - seeking better solutions side. CPR managed to marry the economic interests (let the business people make good business decisions, e.g. resolve on-going relationship issues, as in supplier-vendor disputes in less costly ways), with the qualitative side of dispute resolution (Pareto optimal, wealth maximizing, tailored solutions, with full party participation) organized by sophisticated parties (with or without their lawyers in mediation and other out-of-court processes) (CPR 1987, 1988).

As the critique of the formal litigation system was taken up by "strange bedfellows" (quantitative conservatives who wanted to move cases out of court entirely, or at least away from federal courts, and qualitative progressives ${ }^{11}$ who wanted both more democratic participation in dispute resolution (Merry and Milner 1993) and better outcomes), various forms of dispute resolution, "alternative" to the courts increased in both private use (CPR corporate promotion, family mediation, private contract arbitration) and public promotion (Neighborhood Justice Act for criminal mediation Victim-Offender Mediation -, Umbreit 1994, Menkel-Meadow 2007) and diversion and court-annexed ADR in virtually every court system in America (at both state and federal levels, Menkel-Meadow 2013).

\footnotetext{
${ }^{10}$ In med-arb, the parties choose a third party neutral to facilitate their negotiations for a non-binding resolution, but can ask the mediator to become an arbitrator and decide for them if they reach an impasse in negotiations. In arb-med the parties agree to have a third party decision maker who might then try to facilitate a more consensual solution from the parties instead of deciding for them. There is much controversy in the field of ADR about whether the same person can play both of these roles in a single proceeding, see Menkel-Meadow et. al. 2019.

${ }^{11}$ For a recent discussion of the equivalent strange bedfellows in criminal "restorative justice" reform, see Cohen 2019.
} 
Alternative forms of dispute resolution spread to other domains as well. The American "administrative state" adapted, in the 1980s and 1990s, a new form of participatory rulemaking by developing an "ADR" process called "reg-neg" or negotiated rulemaking in which the regulated and the regulators met before promulgating an administrative regulation to negotiate (with mediated facilitation, Susskind et al. 1999) with all interested parties, in the hopes that negotiation before promulgation of a rule would head off contested litigation after the fact (Harter 1982). This new process of reg-neg led to much academic contest over evaluating its success in cost and litigation reduction and democratic participation (Freeman 1997). While popular for several decades, in the current era of federal de-regulation, after several Republican administrations, there is little reg-neg activity now at the federal level; some still exists at the state level, especially in the western states of Oregon and Washington (and is most often used in environmental disputes, for contingent solutions (which can be changed when science changes - "adaptive management") which are often more appropriate than the hard outcomes of litigation (Camacho and Glicksman 2016) .

Building on "responsive" ADR concepts, a new movement in the United States to develop "problem solving courts" (Berman et al. 2005) has, with some controversy, changed the course of litigation in some matters, including vice courts (prostitution and other "petty" crimes, Cohen and Gruber 2019) family courts, drug courts, juvenile courts - all with the intention of providing services and rehabilitation modes in opposition to more conventional legal punishments or judgments. These hybrid civil, criminal and administrative courts sometimes "divert" cases away from the court settings, but they are intended to offer up a different kind of "justice". Whether they succeed or not has been quite variable, as they are mostly operational at local/city levels of court practice and are often criticized by criminal justice reformers and rights activists as increasing surveillance and social control over people with fewer lawyers, rights and resources (Thompson 2002). One could say there is now an ongoing dialectic in court-non-courtback to court attempts to calibrate the most optimal forms of institutionalization of justice.

With the explosion of mass torts (medical products, environmental disasters, asbestos, tobacco, diet pills and now opioid addiction), usually through the filing of class actions (often followed by threatened bankruptcy actions), entrepreneurial lawyers (both plaintiffs and defendants) began to develop new hybrid forms of mass dispute settlement (class action settlements under Rule 23e of the Federal Rules of Civil Procedure, Menkel-Meadow 1995a) and the mass claim facility (Wellington for Asbestos, Dalkon Shield, Menkel-Meadow 1998; September 11 Victims Compensation Fund, Feinberg 2006) and many others for consumer, insurance and securities claims). These forms of claims administration, although often initially filed in court, removed thousands of cases from full adjudication. Multi-district litigation rules allowed consolidation of cases for "sample trials" and shared discovery which would then set the terms for "grid" based settlement plans based on types of injuries and other criteria. As I write this, a mass settlement plan is being proposed for the current opioid addiction crisis which afflicts millions of people, thousands of governmental units (cities and public hospitals), with particular pharmaceutical companies threatening to file bankruptcy without "global settlement" relief. 
In many of these matters, cases are "filed" but are not fully resolved with traditional adjudication. How should they be counted in quantitative measures of litigation? Attempts to evaluate their "success" at compensation and expressions of catharsis and dignity continue to be widely contested in the academic literature. (Hensler 1995, Menkel-Meadow 1997, Resnik 2015) with little agreement, perhaps because, as I have argued repeatedly, "one size will not fit all." Though compensation in mass claims facilities may, on average, be "lower" than full trial adjudication (as in asbestos and Catholic priest pedophile cases), recovery is usually faster, cheaper (low litigation costs or lawyer fees) and usually confidential (often desired by plaintiffs, as well as defendants). We need process pluralism. Different disputants want different things from dispute resolution. And we will need trained dispute resolution professionals to guide people to the processes that will serve them best. ${ }^{12}$

As large institutions have had to deal with many repetitive disputes, the field of Dispute System Design (Amsler et al. 2020) has developed to help companies, countries and public institutions develop grievance and dispute resolution systems (or as some of us call it, "IDR" (internal dispute resolution) for handling repetitive claims, from employment discrimination to consumer disputes about quality, delivery or price of merchandise, all the way to truth and reconciliation commissions for different remedies in transitional justice. This new field and the institutions and processes it has created clearly "remove" cases and matters from formal justice systems. They often offer the kind of tailored, flexible solutions of mediation (future focused, apologies, some compensation, positive obligations taken on, transfers, promotions and other nonmonetary relief (making them qualitatively different from court outcomes), but also can serve to privatize (see section 4 below) disputes or provide routinized, aggregated solutions that can be less satisfying than an individualized court case for some.

Some American companies and government agencies have developed Ombuds programs (far more common in Europe in both the public and private sectors, see Creutzfeldt 2018) which can operate both internally for employees and externally for customers in order to process claims both more quickly but also in more responsive tailored fashion, using mediation and negotiation processes more than conventional decisional processes.

The newest development in dispute resolution is ODR (online dispute resolution) which takes many forms (Katsh and Rabinovich-Einy 2017, Cortés 2018) including both private company mediation, negotiation and resolution of claims with customers (e.g. eBay) and public forms (increasingly court systems being put online, as in the UK, British Columbia, Canada and in specialty courts, such as Ohio's Property Tax Assessment website (Menkel-Meadow 2016a). While ODR presents a series of new dispute resolution issues about the quality of justice (especially with the issues of algorithmic justice and both explicit biases (in coding) and implicit biases (Eubanks 2018), as well as access, there

\footnotetext{
${ }^{12}$ I have been a mediator, arbitrator, facilitator and dispute system designer in many of these cases (asbestos, Dalkon Shield, Silicon Breast Implant, employment discrimination in the securities industry, etc.) and I have learned that some parties want secret private hearings to tell their story and receive some (rapid) compensation and others want to shout their stories of injustice from the rooftops (or public courthouses) and may or may not want compensation for themselves at all. Some want punishment and retribution (punitive damages) and others would like funds to be donated for the benefit of all similarly situated parties (Menkel-Meadow 1998).
} 
is also the possibility of more rapid and efficient "mass justice." As I and others have argued, using online reputational rating services ("getting to Yelp!") has become, in effect, electronic class action litigation. A well placed publicly asserted complaint can result in compensation or, more importantly, policy changes made more rapidly than any form of litigation (Menkel-Meadow and Dingwall 2017). Much of the \#metoo movement (see section 4 below) used social media to demand (and in many cases) receive "instant justice" (termination from employment of sexual harassment offenders, by using publicity and damage to public reputation (Clarke 2019, Williams et al. 2019). Measurement of both the numbers of such disputes (access for small claims that would never have been made in a court setting) and the quality of dispute resolution received (and the public effects of such resolution) are only beginning to be studied (Sela 2018, Sternlight 2020b). Here the nature of "public" vs "private" forms of dispute resolution is not so clear and may be giving way to a more hybridized set of dispute processes. How these processes will be "adjudicated" if challenged in litigation (absence of due process, need for more public and formal accountability, Tuerkheimer 2019) or by regulatory agencies (EU ODR Consumer Directive) remains to be seen. Although the combination of humans and machines to resolve disputes is a bold new development, I do not see "ODR" as the endpoint in the historical evolution of disputing (see MenkelMeadow 2016a and 2016b).

There is no doubt that the many new (and older forms) of " $\mathrm{A}$ " DR have either removed cases from the courts or resolved issues before they get to filing or adjudication. What is much more difficult to assess is whether, as some have argued, ADR has provided more access to justice by providing more fora for possible resolution of disputed matters, encouraged more social complaining (social media effects, see Williams et al. 2019) and whether newer forms of dispute resolution are providing more disputant satisfaction and creative solutions, as ADR initially promised. After many decades of study, my own answers to these questions are "it depends." More importantly, how disputes should be resolved and what process (litigation or another) is appropriate depends on what the issue in dispute is and who the parties are. Given the ironic convergence of some forms of ADR (mandatory arbitration and negotiated settlements with non-disclosure clauses) with a variety of new (and older) kinds of disputes we can see that the question of whether there is too much litigation depends not on quantification or qualifications of disputes and disputants, but on more differentiated understandings of what litigation and dispute resolution are intended to do in different legal arenas.

\section{Differentiated claims: Variations in what we need litigation for}

Whatever one's views about the right measure of litigation in relation to "alternatives,"13 the emergence of new claims of harms (particularly in the United States, but, in fact, common throughout the modern world) have raised new issues about the function of litigation and its many alternatives. Beginning with a variety of mass torts (asbestos, pharmaceuticals, human and environmental disaster, massive consumer fraud (e.g.,

\footnotetext{
${ }^{13}$ In a report on the status of mediation in the European Union following the 2008 Directive, demonstrating very little uptake in the use of mediation (Menkel-Meadow 2015), it was suggested that nations might set "quotas" on the number or percentages of cases to be sent to mediation, away from litigation (dePalo et al. 2014). I think arbitrary numerical quotas make no sense at all - assignments by case type (long term vs. one shot relationships) might make more sense.
} 
Volkswagen's deception in environmental measures in cars), health care, medical devices and other issues), and now extending to child abuse and pedophilia (Catholic Church and Indian Schools), the \#metoo movement about sexual harassment and assault, Time's Up for gender and race civil rights and unequal pay claims, demands for public accountability and compensation for both individual and institutional wrongdoing have exploded in many nations.

While the claims facilities and class action settlements have been effective and appropriately used in some of these cases, demands for more public reckoning have become common in many of these matters (Hensler et al. 2016). Unfortunately, as a result of a variety of legal practices in the United States and elsewhere, many of these claims have been shrouded in secret settlements. The use of mandatory arbitration clauses in many employment and consumer contracts in the United States have forced many of these cases into private decision-making bodies where only the parties are present and awards are private (Sternlight 2019). In addition, beyond the use of mandatory arbitration clauses, the use of Non-Disclosure Agreements (NDAs) or Non-Cooperation Agreements (preventing legal assistance to others with similar claims; Bauer 2008), after settlements are reached, after negotiation, arbitration or mediation, in so many claims, have silenced victims and protected perpetrators, as well as denying the public important information about these claims, both against individuals and institutional actors.

As the current \#metoo movement in the United States is grappling with the substance and widespread practices of sexual harassment in so many walks of life, proceduralists are grappling with important questions about how such cases can and should be handled (Wexler et al. 2019, Dispute Resolution Magazine Editorial Board 2019, Tuerkheimer 2019). Victims or survivors of various forms of abuse or harm vary greatly in their desires for public confrontations in court or public fora (including the media). At the same time, some of the accused are now claiming "convictions", damage to reputations and loss of employment without due process (see Mayer 2019), defamation and other claims in the popular press, demanding various forms of legal protections or other processes, e.g. some form of restorative justice (Wexler 2019, Wexler et al. 2019, Green 2019).

These new cases ${ }^{14}$ present an important case study of consideration of what process is or should be "due" in such matters, what restrictions on litigation, whether consensual or not. Arbitration is sustained in the United States by legal interpretation as a form of contracting, with assumed "consent," which many find abhorrent, but is still currently the law of the land (Radin 2014, Sternlight 2019). What is legally permissible is not necessarily morally appropriate, as the management of these claims now reveals. These cases suggest that whether there is too much or too little litigation may depend on the nature of the claim - both its substance and its "ripeness" in legal development (McGovern 1989).

The development of tort law doctrine, for example, in common law jurisdictions, has been a slowly evolving process of definitions and specification of liability rules as facts

${ }^{14}$ None of these claims are "new" in the sense that sexual, gender and child abuse and domination have been going on since the beginning of human history. It is only "new" that these issues are now making their way into the public and legal sphere. 
(e.g. tobacco, opioid, asbestos) emerge about the dangerousness of products and doctrines have been developed to assign liability (respondeat superior, strict liability, intentional harm, etc.). Mayo Moran (2019) has recently demonstrated that as the cases in the Catholic Church child abuse scandals continue to be filed in many countries, the substantive law of liability has been altered (statutes of limitations extended or abolished, institutional liability developed, and charitable and sovereign immunity doctrines changed or eliminated) mostly through public litigation and changing interpretations in common law jurisdictions.

These important changes in the law and expansion of liability and recognition of wrongdoing are the product of a combination of media and journalistic attention to these issues and increased public litigation in a variety of different jurisdictions. Efforts to silence victims though non-disclosure agreements continue apace (and different individual victims will make different choices about what to do here), but these cases and the \#metoo movement have caused many observers (myself included) to denounce many of the efforts to deflect these claims to more "informal" processes, such as some of the mass claims processes (Elie 2019).

Recently a number of organizations and commentators have raised significant questions about the legality and morality of these processes and clauses (Centre for Ethics and Law 2018, Szalai 2018, Sturdevant 2019). Scholars and lawyer professional groups are now considering whether the advising of or drafting of particular kinds of clauses (nondisclosure agreements, secrecy and confidentiality agreements, mandatory arbitration clauses or other advice for new "disruptive" businesses) should be prohibited or considered "unprofessional" or "unethical" in some contexts (Bauer 2008, Yablon 2019, Green 2019). Some states have already begun to prohibit certain kinds of non-disclosure agreements in some contexts, e.g. sexual harassment, which is likely to affect the drafting of employment contracts, settlement agreements and confidentiality agreements in mediation, ombuds and other forms of dispute resolution (Tippett 2018, 2019). Employees at such large employers as Google and Facebook have successfully protested to have these companies remove mandatory arbitration clauses (at least in sexual harassment cases) from their contracts and recently a group of law student activists successfully shamed some Big Law firms to remove mandatory arbitration clauses from their summer associate employment contracts (Morris 2018). However, it should also be noted that American courts have already begun to reject state attempts to alter nondisclosure and arbitration agreements under the Federal Arbitration Act, relying on Supreme Court rulings that any effort to single out particular kinds of arbitration agreements (including sexual harassment or other forms of discrimination) is preempted by the FAA; see Latif $v$ Morgan Stanley and Co. (S.D. NY. 18 cv11528, June 26, 2019). California passed legislation in 2019 to prohibit the use of mandatory arbitration clauses in employment ( $\mathrm{AB}$ 51) which was rapidly enjoined by a federal court as being pre-empted by the Federal Arbitration Act (now on appeal as of this writing). Whether such new rules and policies will increase litigation in these areas remains to be seen.

Consider two disturbing examples. In 2005 a female sales representative sued Dov Charney, the CEO and founder of American Apparel, of sexual harassment (Nelson $v$ American Apparel, Inc., 2008, Slater 2008). The parties agreed to a settlement (offered by the defendants) in which the parties would appear before an arbitrator, chosen by the 
defendants, and the arbitrator would confirm a pre-arranged award and opinion which would state that Mr. Charney had not committed any acts of sexual harassment and his "offensive" speech at the workplace was protected by the US Constitution's First Amendment speech protections and that he could issue a press release that he had been vindicated by the arbitrator's award. ${ }^{15}$ After confirmation of the arbitration agreement, with a confidentiality agreement contained within it about the case, the plaintiff was to receive 1.3 million dollars in settlement. On the date of the scheduled arbitration, the plaintiff's lawyers did not appear and the chosen arbitrator, a retired judge, refused to sign or confirm the arbitration as it appeared to be a "sham arbitration". The defendants sued in a trial court to order the plaintiff to attend the arbitration. The defendants asked that all legal proceedings be sealed, as per the confidentiality agreement in the settlement agreement. The trial court denied the motion to compel the arbitration and the defendants appealed. The appellate court (Court of Appeals, an intermediate court in California) did not seal the filings, but it compelled arbitration of the issue of confidentiality of the settlement agreement and said under both federal and state arbitration law, it could not rule on the merits of whether the arbitration was "fake," illegal or a sham. The case then was reported, with much expressed outrage, in newspapers throughout the US (Wall Street Journal and California newspapers). Subsequently, the Court of Appeals decision was "depublished" in California, a rather unique and strange rule of civil procedure which allows judges to de-certify a decided case so that it cannot be used for precedent and be cited (California Rules of Court, Rule 8.1115(a). I used this case as an examination question in my course on ADR in 2008, asking students how they would rule as a judge on the enforceability of both the underlying settlement agreement, and the arbitration and confidentiality agreement under the relevant arbitration statutes, and any other arguments they could see (e.g. a public policy argument for voiding the agreement and the confidentiality provision). Since there have been no further public reports of this particular case one can assume it was later settled in confidence, probably for a larger sum. Readers of this paper should know that subsequently, many years later, Mr. Charney was removed from his position at American Apparel because of repeated instances of sexual harassment and improper conduct. All of this occurred long before the recent exposure, by the \#metoo movement, of repeated sexual harassment by many noted entertainment figures and prominent journalists (producer Harvey Weinstein ${ }^{16}$ [Farrow 2017, 2019], actor Kevin Spacey, Matt Lauer (NBC), Charlie Rose (PBS) and many TV journalists at Fox, e.g. Roger Ailes and Bill O'Reilly (the Right Wing TV broadcast channel in the US; see Carlson 2017 for memoir of personal experiences, and see Green 2019 for summaries of claims and a unique proposal for limiting defences of the accused).

Within our own world of academia, many cases have been settled privately, with nondisclosure and confidentiality agreements, but a few which have made it into the public eye expose the dangers of "anti-litigation" practices and policies. A Canadian law

\footnotetext{
15 This is a fairly bizarre statement in itself as the first amendment in the United States constitution applies to state action, not private statements in a private workplace setting.

16 Efforts to settle the Harvey Weinstein civil suits (the first criminal trial in New York has just been completed with criminal; convictions on two counts, including rape, and Mr. Weinstein will face other criminal charges in California) for $\$ 44$ million have recently fallen apart as there is dissention among the various plaintiffs now collected into a proposed class action settlement (Perman 2019).
} 
professor, Emir Crowne, was accused by a group of students and faculty at the University of Windsor of a variety of inappropriate (sexual harassment, favoritism, falsifying credentials) activities. A formal university investigation was ordered and Prof. Crowne was terminated with a confidential settlement between his faculty union and the University which contained a non-disclosure clause about the settlement accompanying the dismissal. When Professor Crowne was then subsequently employed as an adjunct professor at another Ontario law school and later at the University of the West Indies, some faculty (notably ADR scholar, Distinguished Professor Julie Macfarlane) were asked about their own percipient knowledge of Professor Crowne's activity by these universities to prevent further harm to other students, where it was clear subsequent putative employers seemed to be unaware of the repeated activity of Mr. Crowne. Although Professor Macfarlane is not a party to the university's Nondisclosure agreement, Mr. Crowne has now sued Professor Macfarlane for defamation in the courts of Trinidad and Tobago (where he currently resides). The University of Windsor (Professor Macfarlane's employer) and its insurance carrier, Canadian Universities Reciprocal Insurance Exchange, initially failed to provide indemnity or defense insurance coverage for her and the case became a public cause celebre for those seeking to expose the dangers of non-disclosure agreements (as in the Catholic Church cases) where non-disclosure of bad behavior and confidential transfers to new positions allows perpetrators to continue to move on to other positions and continue to harm others. ${ }^{17}$ In the summer of 2019 the Superior Court of Ontario ruled that the insurance company must defend Professor Macfarlane for claims of defamation, which clearly "arose out of her employment," and allow her to choose her legal representative (Macfarlane v Canadian Universities Reciprocal Insurance Exchange, ONSC 4631, 2019).

These kinds of cases which have caused great physical and mental distress harms, as well as substantial monetary damages, to many people (faulty medical products, employment and discriminatory bad practices, contract breaches, consumer and securities frauds) are problematic because they involve both individual harm to be compensated or dealt with through traditional legal doctrines, but also implicate larger social and public issues.

When does an individual have a "right" or desire to protect their own privacy in accepting a settlement of money in return for an agreement to keep silent, either to protect one's own privacy (as in health issues (reproductive rights, AIDS-HIV, employment future) or when a defendant or wrong-doer seeks to protect their own privacy and fend off future and more public actions? When does the public have a "right to know" about someone else's harm? Who owns a legal dispute? (Christie 1977, MenkelMeadow 1995b). Many years ago one of my teaching assistants traded several million dollars in a race discrimination case against his law firm (Zelleke $v$ White and Case [unpublished], Stevens and Holden 1994, Baynes 2003) in order to refuse a demand for confidentiality because he was more interested in a public "shaming" of the law firm's behavior. The large settlement he received, without the confidentiality agreement, appeared on the front page of our local (Los Angeles Times) newspaper so that the wrongful conduct sued about would remain public, even after settlement of the lawsuit!

\footnotetext{
17 For those who are inclined, there is a GoFundMe site to contribute funds for Prof. Macfarlane's defense fund and campaign to end Non-disclosure agreements at https://www.gofundme.com/EndNDAs.
} 
As I often say, "different strokes for different folks" - when people sue over legal harms, they will have preferences about what they want to accomplish with their lawsuits. Some are more concerned with compensation and private resolution. Others prefer the publicity of shaming the wrongdoing. A litigation system, in my view, should permit parties to select and control their own preferences. The use of mandatory arbitration clauses, confidentiality and non-disclosure agreements routinely used and sustained by courts diminishes that control over proper justice, for both individuals and the larger public.

Beyond the "newer" claims of the sexual harassment of \#metoo and institutional and individual child abuse, mandatory arbitration, coupled with decisions of the US Supreme Court permitting the waiver of class actions in litigation and arbitration have, in effect, foreclosed both individual and class action litigation in a wide area of legal disputes (employment, Wal-Mart v Dukes, 2011, consumer disputes, ATET Mobility v Concepcion, 2011, prisoner's civil rights, Schlanger 2004) and corporate securities and governance disputes, Shapira 2019). Diminution of rights to file both individual and class action claims (by Supreme Court decision and federal legislation) has produced an outpouring of critique by scholars, lawyers and activists who claim that together these procedural and substantive legal doctrines prevent public airing of important information (not only in the outcomes and results but in the hiding of discovery documents and other information that usually accompanies public litigation). Thus, many critics suggest that even if private disputing and even mandatory arbitration might be desired by a party seeking privacy, or efficiency for a company seeking cheaper and faster dispute resolution, the loss of information and "market discipline" through public "shaming" (in corporate settings, Shapira 2019) of public reputational claims in litigation may not be so good for the polity (or the economy).

\section{Policy implications}

So what doctrines or policies can properly adjudicate the tensions between "too much or too little litigation" and personal choice and autonomy with respect to what should happen to legal claims? Should the harmed (plaintiffs) control how their cases are ultimately handled? When should our legal doctrines and policies trump individual desires and choices because of an important public "right to know" about relevant wrongdoing?

Several decades ago dispute resolution scholars wrote about the need to "crack" or open secret settlements when important public health issues were at stake (Menkel-Meadow 1993) and several states, whether by statute, or case by case litigation, ruled on case-bycase bases when particular secret settlements had to be "unsealed" (tobacco settlements, dangerous products, building conditions, sexual predators, etc.). Some states now deal with these issues in their rules of civil procedure, giving judges the discretion to open or close particular proceedings or settlements. In the current climate, at least 16 American states are passing statutes allowing the voiding of confidentiality or secrecy clauses in sexual harassment cases, though there are likely to be many legal challenges here (some already successful at voiding or limiting these statutes).

One scholar suggests legislation that would prevent high-level executives from using "consent" as a defense in any sexual harassment claim (Green 2019); another scholar 
simply argues that it would not be good for American business if all corporations used mandatory arbitration clauses to provide for private justice in corporate governance challenges (Shapira 2019).

There are now likely to be conflicts in suggested solutions to these issues. Some victims will still want confidentiality and secrecy to protect their own privacy; a different interest than the use of confidentiality clauses to protect perpetrators. Some agreements, which require "positive references" in employment cases, to end the dispute, or nondisparagement clauses to protect the accused, actually either force or "limit" speech in ways that are likely to be challenged under American free speech doctrine. In the employment setting, those accused of wrongdoing who are terminated then turn around and sue their former employers for wrongful termination and or defamation, limiting what employers are likely to say about former employees when they move on. As analogies are drawn to child abuse (mandatory reporting in virtually all states) or statutory rape, (consent is not legally possible under a particular age) legislation seeking to deal with certain harms are likely to trump or conflict with a variety of practices used to settle or deflect cases from court. Both the state and individual parties may not fully understand what these clauses and terms mean and what effects they may have in the future.

The significance of this "new" round of claims, both mass and individual, is that they fully expose the difficulties and contradictions in assessing how much litigation is too much or too little and also how difficult it will be to promulgate policy generally for different kinds of cases, especially those with conflicting private and public interests. Parties have different preferences for how much they want revealed in public courtrooms (so deciding what to do if parties in the same dispute have different preferences is difficult enough). What, as a matter of "policy," we think should or must be revealed in a public court setting for a variety of public interests and reasons may be difficult to assess in advance. At what point in the Catholic Church or Harvey Weinstein repeated wrongdoing cases should the public have an "interest" in formal prosecution and/or civil suits, regardless of what the parties might desire?

There are no easy answers to these questions - my own "balancing" of interests from a common law background is that litigation and "alternatives" must be balanced and weighed in differentiated settings. As a matter of public policy, I would permit judges, in appropriate cases, to "void" non-disclosure or secrecy agreements, in matters affecting "the public interest" (a vague standard, I know). I also believe (contrary to current US Supreme Court jurisprudence) that the use of mandatory arbitration clauses and class action waivers, which essentially restrict complainants and disputants to only one form of (usually inadequate) process (arbitration in private, rather than litigation in public), is not only unethical (for those who draft such clauses in contracts, knowing full well their effects), but contrary to democratic values within the American (AngloAmerican, European, Western) canon of procedural justice and "the rule of law". Other scholars have suggested that these are public issues when they affect many people and must not be relegated to non-legal resolution (including "media justice") but must be handled with formality and public discipline and compensation in both civil and, where appropriate criminal, proceedings. When there is common and widespread "suppression" of litigation we know there is not "too much litigation," but too little! 
So the study of litigation from a quantitative perspective, (how much litigation, what kinds of cases etc.) is important, but without a qualitative and jurisprudential assessment (West 2011), of what kinds of cases and matters are important for a litigation or other dispute resolution process, in terms of substantive justice and democratic process values, we cannot answer the questions of whether there is "too much" or "too little" litigation, with numbers alone. As always in a common law system, the answer to this question is "it depends". On what we value!

\section{References}

Abel, R.L., 1987. The Real Tort Crisis - Too Few Claims. Ohio State Law Journal [online], 48, 443-67. Available from:

https://heinonline.org/HOL/LandingPage?handle=hein.journals/ohslj48\&div=29\& id=\&page $=$ [Accessed 4 March 2020].

Alberstein, M., 2015. Judicial Conflict Resolution (JCR): A New Jurisprudence for an Emerging Judicial Practice. Cardozo Journal of Conflict Resolution, 16, 879-965.

Alexander, J., 2016. Do the Merits Matter? A Study of Settlements in Securities Class Actions. In: C.A. Hill and B.H. McDonnell, eds., Economics of Corporate Law. Cheltenham: Edward Elgar.

Ali, S., 2018. Court Mediation Reform: Efficiency, Confidence and Perceptions of Justice. Cheltenham: Edward Elgar.

Amsler, L.B., Martinez, J.K., and Smith, S.E., 2020. Dispute System Design: Preventing, Managing and Resolving Conflict. Palo Alto: Stanford University Press.

Baker, T., 2007. The Medical Malpractice Myth. University of Chicago Press.

Bauer, J., 2008. Buying Witness Silence: Evidence-Suppressing Settlements and Lawyers' Ethics. Oregon Law Review [online], vol. 87, 481. Available from: https://scholarsbank.uoregon.edu/xmlui/bitstream/handle/1794/9181/Bauer.pdf?s equence $=1 \&$ is Allowed $=y$ [Accessed 4 March 2020].

Baynes, L.M., 2003. Falling Through the Cracks: Race and Corporate Law Firms. St. John's Law Review [online], 77(4), 785-836. Available from:

https://scholarship.law.stjohns.edu/lawreview/vol77/iss4/6 [Accessed 4 March 2020].

Berman, G., Feinblatt, J., and Glazer. S., 2005. Good Courts: The Case for Problem Solving Justice. New York: New Press.

Burbank, S.B., and Farhang, S., 2017. Rights and Retrenchment: The Counterrevolution against Federal Litigation. Cambridge University Press.

Burger, W., 1982. Isn't There a Better Way? ABA Journal, 68, 274.

Camacho, A.E., and Glicksman, R.L., 2016. Legal Adaptive Capacity: How Program Goals and Processes Shape Federal Land Adaptation to Climate Change. University of Colorado Law Review [online], 87, 711-826. Available from: https://ssrn.com/abstract=2629363 [Accessed 4 March 2020].

Carlson, G., 2017. Be Fierce: Stop Harassment and Take Your Power Back. New York: Center Press. 
Center for Public Resources (CPR), 1987. ADR and the Courts: A Manual for Judges and Lawyers. New York: Butterworth Legal Publishers.

Center for Public Resources (CPR), 1988. Containing Legal Costs: ADR Strategies for Corporations, law Firms and Government. New York: Butterworth Legal Publishers.

Centre for Ethics and Law, 2018. Ethics and NDAs [online]. University College London Faculty of Laws, April. Available from:

https://www.ucl.ac.uk/laws/sites/laws/files/ethics_and_ndas.pdf [Accessed 4 March 2020].

Christie, N., 1977. Conflicts as Property. The British Journal of Criminology [online], 17(1), 1-15. Available from: https://doi.org/10.1093/oxfordjournals.bjc.a046783 [Accessed 4 March 2020].

Clarke, J.A., 2019. The Rules of \#MeToo. University of Chicago Legal Forum [online], vol. 2019, art. 3, 37-84. Available from:

https://chicagounbound.uchicago.edu/uclf/vol2019/iss1/3/ [Accessed 4 March 2020].

Cohen, A., 2019. Moral Restorative Justice: A Political Genealogy of Activism and Neoliberalism in the United States. Minnesota Law Review [online], 104(2). Available from: https://minnesotalawreview.org/wpcontent/uploads/2019/12/Cohen_PDF_Final.pdf [Accessed 4 March 2020].

Cohen, A., and Gruber, A., 2019. Governance Feminism in New York's Human Trafficking Intervention Courts. In: J. Halley et al., eds., Governance Feminism: A Handbook. University of Minnesota Press.

Cortés, P., 2018. The Law of Consumer Redress in an Evolving Digital Market: Upgrading from Alternative to Online Dispute Resolution [online]. Cambridge University Press. Available from: https://doi.org/10.1017/9781139940900 [Accessed 4 March 2020].

Creutzfeldt, N., 2018. Ombudsmen and ADR: A Comparative Study of Informal Justice in Europe [online]. Cham: Palgrave Macmillan. Available from: https://doi.org/10.1007/978-3-319-78807-4 [Accessed 4 March 2020].

de Tocqueville, A., 1835. Democracy in America (vol. 1). New York: Vintage Books. dePalo, G., et al., 2014. Rebooting EU Mediation Report, prepared for European Parliament, Policy Department C: Citizen Rights and Constitutional Affairs. Directorate General for Internal Policies.

Dispute Resolution Magazine Editorial Board, ed., 2019. Dispute Resolution Magazine, Winter 2019, 25(2-\#MeToo: Special Issue), 5-24.

Edelman, L., 2016. Working Law: Courts, Corporations and Civil Rights. University of Chicago Press.

Elie, P., 2019. What do the Church's Victims Deserve? The New Yorker [online], 15 April. Available from: https://newyorker.com/magazine/2019/04/15/what-do-thechurchs-victims-deserve [Accessed 4 March 2020]. 
Engel, D., 2016. The Myth of the Litigious Society: Why We Don't Sue [online]. University of Chicago Press. Available from: https://doi.org/10.7208/chicago/9780226305189.001.0001 [Accessed 4 March 2020].

Eubanks, V., 2018. Automating Inequality: How High-Tech Tools Profile, Police and Punish the Poor. New York: St. Martin's Press.

Farhang, S., 2010. The Litigation State: Public Regulation and Private Lawsuits in the United States [online]. Princeton University Press. Available from: https://doi.org/10.1515/9781400836789 [Accessed 4 March 2020].

Farrow, R., 2017. From Aggressive Overtures to Sexual Assault: Harvey Weinstein Accusers Tell Their Stories. The New Yorker [online], 10 October. Available from: https://www.newyorker.com/news/news-desk/from-aggressive-overtures-tosexual-assault-harvey-weinsteins-accusers-tell-their-stories [Accessed 4 March 2020].

Farrow, R., 2019. Catch and Kill: Lies, Spies and a Conspiracy to Protect Predators. New York: Little Brown.

Feinberg, K., 2006. What Is Life Worth? The Unprecedented Effort to Compensate the Victims of 9/11. New York: Public Affairs.

Felstiner, W.I.F., Abel, R.L., and Sarat, A., 1980-81. The Emergence and Transformation of Disputes... Naming, Blaming and Claiming. Law and Society Review [online], 15(3/4), 631-654. Available from: https://doi.org/10.2307/3053505 [Accessed 4 March 2020].

Fisher, R., and Ury, W., (with B. Patton), 2011. Getting to Yes: Negotiating Agreement Without Giving In. $3^{\text {rd }}$ ed. New York: Penguin. (Originally published in 1982).

Fiss, O.M., 1984. Against Settlement. The Yale Law Journal [online], 93(6), 1073. Available from: https://doi.org/10.2307/796205 [Accessed 4 March 2020].

Forbath, W., 1991. Law and the Shaping of the American Labor Movement. Cambridge, MA: Harvard University Press.

Freeman, J., 1997. Collaborative Governance in the Administrative State. UCLA Law Review [online], 45(1). Available from: https://ssrn.com/abstract=11408 [Accessed 4 March 2020].

Galanter, M., 1983. Reading the Landscape of Disputes: What We Know and Don't Know (and Think We Know) about Our Allegedly Contentious and Litigious Society. UCLA Law Review, 31, 4-71.

Galanter, M., 1986. The Day After the Litigation Explosion. Maryland Law Review, 46, 339.

Galanter, M., 2004. The Vanishing Trial: An Examination of Trials and Related Matters in Federal and State Courts. Journal of Empirical Legal Studies [online], 1(3), 459. Available from: https://doi.org/10.1111/j.1740-1461.2004.00014.x [Accessed 4 March 2020].

Genn, H., 2009. Judging Civil Justice [online]. Cambridge University Press. Available from: https://doi.org/10.1017/CBO9781139192378 [Accessed 4 March 2020]. 
Gilles, M., 2016. The Day Doctrine Died: Private Arbitration and the End of Law. University of Illinois Law Review [online], 2016(2), 371-424. Available from: https://illinoislawreview.org/print/volume-2016-issue-2/the-day-doctrine-diedprivate-arbitration-and-the-end-of-law/ [Accessed 4 March 2020].

Glover, M., 2017. A Regulatory Theory of Legal Claims. Vanderbilt Law Review [online], 70(1), 221-309. Available from: https://wp0.vanderbilt.edu/lawreview/2017/01/aregulatory-theory-of-legal-claims/ [Accessed 4 March 2020].

Green, M., 2019. A New \#MeToo Result: Rejecting Notions of Romantic Consent with Executives. Employee Rights and Employee Policy Journal [online]. Available from: https://scholarship.law.tamu.edu/facscholar/1389/ [Accessed 20 July 2020].

Hans, V., and Vidmar, N., 1986. Judging the Jury [online]. New York: Plenum Press. Available from: https://doi.org/10.1007/978-1-4899-6463-2 [Accessed 4 March 2020].

Harter, P.J., 1982. Negotiating Regulations: A Cure for Malaise. Georgetown Law Journal [online], 71, 1. Available from:

https://www.acus.gov/sites/default/files/documents/1982-

04\%20Procedures\%20for\%20Negotiating\%20Proposed \%20Regulations.pdf [Accessed 4 March 2020].

Heinzerling, L., 2019. A Meditation on Juliana v United States [online]. Available from: https://doi.org/10.2139/ssrn.3395471 [Accessed 4 March 2020].

Hensler, D., 1995. A Glass Half Full. A Glass Half Empty: The Use of Alternative Dispute Resolution in Mass Personal Injury Litigation. Texas Law Review, 73, 1587.

Hensler, D., Hodges, C., and Tzankova, I., eds., 2016. Class Actions in Context: How Culture Politics and Economics Shape Collective Action [online]. Cheltenham: Edward Elgar. Available from: https://doi.org/10.4337/9781783470440 [Accessed 4 March 2020].

Horowitz, M., 1977. The Transformation of American Law 1780-1860. Cambridge, MA: Harvard University Press.

Horowitz, M., 1992. The Transformation of American Law 1870-1960. New York: Oxford University Press.

Howard, P.K., 1994. The Death of Common Sense: How Law is Suffocating America. New York: Random House.

Kagan, R., 2001. Adversarial Legalism: The American Way of Law. Cambridge, MA: Harvard University Press.

Kantor, J., and Twohey, M., 2019. She Said: Breaking the Sexual Harassment Story That Helped Ignite a Movement. New York: Penguin Press.

Katsh, E., and Rabinovich-Einy, O., 2017. Digital Justice: Technology and the Internet of Disputes [online]. New York: Oxford University Press. Available from: https://doi.org/10.1093/acprof:oso/9780190464585.001.0001 [Accessed 4 March 2020]. 
Katvan, E., et al., eds., 2017. Too Many Lawyers?: The Future of the Legal Profession. London/New York: Routledge.

Kritzer, H.M., 1986. Adjudication to Settlement: Shading in the Gray. Judicature, 70, $161-65$.

Kritzer, H.M., 2004. Advocacy and Rhetoric vs. Scholarship and Evidence in the Debate over Contingency Fees: A Response to Professor Brickman. Washington University Law Quarterly, 82, 477-97.

Lahav, A.L., 2006. The Roles of Litigation in American Democracy. Emory Law Journal [online], 65, 1657-1704. Available from:

http://law.emory.edu/elj/_documents/volumes/65/6/lahav.pdf [Accessed 4 March 2020].

Lind, A.E., and Tyler, T., 1988. The Social Psychology of Procedural Justice [online]. New York: Plenum Press. Available from: https://doi.org/10.1007/978-1-4899-2115-4 [Accessed 4 March 2020].

Luban, D., 1995. Settlements and the Erosion of the Public Realm. Georgetown Law Journal, 83, 2619-62.

Manning, B., 1977. Hyperlexis: Our National Disease. Northwestern University Law Review, 71(6), 767-782.

Mayer, J., 2019. The Case of Al Franken: A close look at the accusations against the former Senator. The New Yorker [online], 29 July. Available from: https://www.newyorker.com/magazine/2019/07/29/the-case-of-alfranken?currentPage=all [Accessed 4 March 2020].

McGovern, F., 1989. Resolving Mature Mass Tort Litigation. Boston University Law Review [online], 69, 659. Available from: https://scholarship.law.duke.edu/faculty scholarship/673/ [Accessed 4 March 2020].

Menkel-Meadow, C., 1979. The 59th Street Clinic: Evaluation of the Experiment. Chicago: ABA Press.

Menkel-Meadow, C., 1984. Toward Another View of Legal Negotiation: The Structure of Problem-Solving. UCLA Law Review, 31, 754-842.

Menkel-Meadow, C., 1993. Public Access to Private Settlements: Conflicting Legal Policies. Alternatives to High Costs of Litigation [online], 11(6), 85-87. Available from: https://doi.org/10.1002/alt.3810110608 [Accessed 4 March 2020].

Menkel-Meadow, C., 1995a. Ethics of Mass Torts Settlements: When the Rules Meet the Road. Cornell Law Review [online], 80(4), 1159. Available from: https://scholarship.law.cornell.edu/clr/vol80/iss4/14/ [Accessed 4 March 2020].

Menkel-Meadow, C., 1995b. Whose Dispute Is It, Anyway? A Philosophical and Democratic Defense of Settlement (In Some Cases). Georgetown Law Journal [online], 83, 2663-2696. Available from: https://scholarship.law.georgetown.edu/facpub/1767/ [Accessed 4 March 2020]. 
Menkel-Meadow, C., 1996. The Trouble with The Adversary System in a Post-Modern, Multi-cultural World. William and Mary Law Review [online], 38, 5-44. Available from: https://scholarship.law.georgetown.edu/facpub/1745 [Accessed 5 March 2020].

Menkel-Meadow, C., 1997. When Dispute Resolution Begets Disputes of its Own: Conflicts Among Dispute Professionals. UCLA Law Review [online], 44, 1871. Available from: https://scholarship.law.georgetown.edu/facpub/1762 [Accessed 5 March 2020].

Menkel-Meadow, C., 1998. Taking the Mass Out of Mass Torts: Reflections of a Dalkon Shield Arbitrator on Alternative Dispute Resolution, Judging, Neutrality, Gender and Process. Loyola of Los Angeles_Law Review [online], 31, 513-550. Available from: https://scholarship.law.georgetown.edu/facpub/1761 [Accessed 5 March 2020].

Menkel-Meadow, C., 2000. Mothers and Fathers of Invention: The Intellectual Founders of ADR. Ohio State Journal on_Dispute Resolution [online], 16(1), 1-37. Available from: https://scholarship.law.georgetown.edu/facpub/523 [Accessed 5 March 2020].

Menkel-Meadow, C., 2001. Aha? Is Creativity Possible in Legal Problem Solving and Teachable in Legal Education? Harvard Negotiation. Law Review [online], 6, 97-144. Available from: https://scholarship.law.georgetown.edu/facpub/177 [Accessed 5 March 2020].

Menkel-Meadow, C., 2002. When Litigation is Not the Only Way: Consensus Building and Mediation as Public Interest Lawyering. Washington University Journal of Law and Policy [online], 10(1), 37-61. Available from:

https://openscholarship.wustl.edu/law journal law policy/vol10/iss1/4 [Accessed 5 March 2020].

Menkel-Meadow, C., 2003. Dispute Processing and Conflict Resolution: Theory, Practice and Policy. Farnham: Ashgate.

Menkel-Meadow, C., 2006a. Peace and Justice: Notes on the Evolution and Purposes of Plural Legal Processes. Georgetown Law Journal [online], 94, 553-580. Available from: https://scholarship.law.georgetown.edu/fac lectures/10/ [Accessed 5 March 2020].

Menkel-Meadow, C., 2006b. Why Hasn't The World Gotten To Yes?: An Appreciation and Some Reflections. Negotiation Journal [online], 22(3), 485-503. Available from: https://doi.org/10.1111/j.1571-9979.2006.00119.x [Accessed 5 March 2020].

Menkel-Meadow, C., 2007. Restorative Justice: What Is It and Does It Work? Annual Review of Law and Social Science [online], vol. 3, 161-187. Available from: https://doi.org/10.1146/annurev.lawsocsci.2.081805.110005 [Accessed 5 March 2020].

Menkel-Meadow, C., 2009. Are There Systemic Ethics Issues in Dispute System Design? And What We Should (Not) Do About It: Lessons from International and Domestic Fronts. Harvard Negotiation. Law Review [online], vol. 14, 195-231. Available from: 
https://scholarship.law.uci.edu/cgi/viewcontent.cgi?article=1207\&context=faculty scholarship [Accessed 5 March 2020].

Menkel-Meadow, C., 2010. Empirical Studies of ADR: The Baseline Problem of What ADR Is and What It is Compared To. In: P. Cane and H. Kritzer, eds., Oxford Handbook of Empirical Legal Research. Oxford University Press.

Menkel-Meadow, C., 2013. Regulation of Dispute Resolution in the United States of America: From the Formal to the Informal to the Semi-Formal. In: F. Steffek et al., eds., Regulation of Dispute Resolution - ADR and Access to Justice at the Crossroads. Oxford/Portland: Hart.

Menkel-Meadow, C., 2015. Variations in the Uptake of and Resistance to Mediation Outside of the United States. In: A. Rovine, ed., Contemporary Issues in International Arbitration and Mediation: The Fordham Papers 2014 [online]. Leiden: Brill Nijhoof, pp. 189-221. Available from: https://doi.org/10.1163/9789004305595015 [Accessed 5 March 2020].

Menkel-Meadow, C., 2016a. Is ODR ADR? Reflections of an ADR Founder from $15^{\text {th }}$ ODR Conference, The Hague. International Journal of Online Dispute Resolution [online], 3(1), 4. Available from: https://doi.org/10.5553/IJODR/235250022016003001002 [Accessed 5 March 2020].

Menkel-Meadow, C., 2016b. Mediation and Its Applications for Good Decision Making and Dispute Resolution [online]. London/Antwerp: Intersentia. Available from: https://doi.org/10.1093/obo/9780195396607-0192 [Accessed 5 March 2020].

Menkel-Meadow, C., 2018. Mediation 3.0: The Uses and Problems with Technology in Dispute Resolution. Asian Journal on Mediation, 1-22.

Menkel-Meadow, C., 2020. Hybrid and Mixed Dispute Resolution Processes: Integrities of Process Pluralism. In: M. Palmer, M. Roberts and M. Moscati, eds., Comparative Dispute Resolution Research Handbook. Cheltenham: Edward Elgar.

Menkel-Meadow, C., and Dingwall, R., 2017. Scripts: What to Do When Big Bad Companies Won't Negotiate. In: C. Honeyman and A.K. Schneider, eds., Negotiator's Desk Reference. St Paul: DRI.

Menkel-Meadow, C., and Garth, B., 2010. Civil Procedure and Courts. In: P. Cane and H. Kritzer, eds., The Oxford Handbook of Empirical Legal Research [online]. Oxford University Press. Available from:

https://doi.org/10.1093/oxfordhb/9780199542475.013.0029 [Accessed 5 March 2020].

Menkel-Meadow, C., et al., 2019. Dispute Resolution: Beyond the Adversary Model. $3^{\text {rd }}$ ed. New York: Wolters Kluwer Law and Business.

Merry, S.E., 1990. Getting Justice and Getting Even: Legal Consciousness among WorkingClass Americans. University of Chicago Press.

Merry, S.E., and Milner, N., 1993. The Possibility of Popular Justice: A Case Study of Community Mediation in the United States [online]. Ann Arbor: Michigan University Press. Available from: https://doi.org/10.3998/mpub.13313 [Accessed 5 March 2020]. 
Miller, R.E, and Sarat, A., 1980-81. Grievances, Claims, and Disputes: Assessing the Adversary Culture. Law and Society Review [online], 15(3/4), 525-566. Available from: https://doi.org/10.2307/3053502 [Accessed 5 March 2020].

Mnookin, R.M., and Kornhauser, L., 1979. Bargaining in the Shadow of the Law: The Case of Divorce. Yale Law Journal [online], 88(5), 950. Available from: https://doi.org/10.2307/795824 [Accessed 5 March 2020].

Moran, M., 2019. Cardinal Sins: How the Catholic Church Sexual Abuse Crisis Changed Private Law. Georgetown Journal of Gender and the Law [online], XXI. Available from: https://doi.org/10.2139/ssrn.3373968 [Accessed 5 March 2020].

Morris, A., 2018. Why 3 BigLaw Firms Ended Use of Mandatory Arbitration Clauses. ABA Journal [online], 1 June. Available from:

http://www.abajournal.com/magazine/article/biglaw mandatory arbitration cla uses [Accessed 5 March 2020].

Nelson, R., and Nielsen, L.B., 2005. Rights Realized? An Empirical Analysis of Employment Discrimination as A Claiming System. Wisconsin Law Review, 2005(2), 663-712.

Nolan-Haley, J., Deason, E.E., and Hernandez-Crespo Gonstead, M., 2019. Global Issues in Mediation. St. Paul: West Academic.

Perman, S., 2019. Deal at Risk as Mogul's Accusers Bicker. Los Angeles Times [online], 5 June. Available from:

https://enewspaper.latimes.com/infinity/article share.aspx?guid=61e1de45-4de240f7-a3fe-d69ebae4612e [Accessed 5 March 2020].

Radin, M., 2014. Boilerplate: The Fine Print, Vanishing Rights and the Rule of Law [online]. Princeton University Press. Available from: https://doi.org/10.1515/9781400844838 [Accessed 5 March 2020].

Resnik, J., 2011. Fairness in Numbers: A Comment on AT\&T Mobility v Concepcion, Wal-Mart v Dukes and Turner v Rogers. Harvard Law Review [online], 125, 78-170. Available from: https://harvardlawreview.org/2011/11/fairness-in-numbers-acomment-on-att-v-concepcion-wal-mart-v-dukes-and-turner-v-rogers/ [Accessed 5 March 2020].

Resnik, J., 2015. Diffusing Disputes: The Public in the Private of Adjudication, the Private in Courts and the Erasure of Rights. Yale Law Journal [online], 124, 2804. Available from: https://digitalcommons.law.yale.edu/cgi/viewcontent.cgi?article=5950\&context=fs s_papers [Accessed 5 March 2020].

Rosenberg, G., 2008. The Hollow Hope: Can Courts Bring About Social Change? [online]. University of Chicago Press. Available from: https://doi.org/10.7208/chicago/9780226726687.001.0001 [Accessed 5 March 2020].

Saks, M., 1992. Do We Really Know Anything about the Behavior of the Tort Litigation System and Why Not? University of Pennsylvania Law Review [online], 140(4), 1147-1292. Available from: https://doi.org/10.2307/3312403 [Accessed 5 March 2020]. 
Saks, M., 1993. Malpractice Misconceptions and Other Lessons about the Litigation System. Justice System Journal [online], 16(2), 7-19. Available from: https://doi.org/10.1080/23277556.1993.10871169 [Accessed 5 March 2020].

Sandefur, R., 2014. Accessing Justice in the Contemporary USA: Findings from the Community Needs and Services Study [online]. Chicago: American Bar Foundation. Available from: https://doi.org/10.2139/ssrn.2478040 [Accessed 5 March 2020].

Sandefur, R., 2016. What We Know and Need to Know about the Legal Needs of the Public. University of South Carolina Law Review [online], vol. 667. Available from: https://ssrn.com/abstract=2949010 [Accessed 5 March 2020].

Sander, F.E.A., 1976. Varieties of Dispute Processing. F.R.D., 70, 79-132.

Scheingold, S., 1974. The Politics of Rights: Lawyers, Public Policy and Political Change. New Haven: Yale University Press.

Schlanger, M., 2004. The Politics of Inmate Litigation. Harvard Law Review [online], 117(8), 2799-803. Available from: https://doi.org/10.2307/4093420 [Accessed 5 March 2020].

Sela, A., 2018. Can Computers Be Fair? How Automated and Human-Powered Online Dispute Resolution Affect Procedural Justice in Mediation and Arbitration. Ohio State Journal on Dispute Resolution, 33(1), 91-148.

Shapira, R., 2019. Mandatory Arbitration and the Market for Reputation. Boston University Law Review [online], 99(3), 873-914. Available from: https://doi.org/10.2139/ssrn.3376781 [Accessed 5 March 2020].

Shapiro, M., 1981. Courts: A Comparative and Political Analysis [online]. University of Chicago Press. Available from:

https://doi.org/10.7208/chicago/9780226161341.001.0001 [Accessed 5 March 2020].

Slater, D., 2008. The Story Behind American Apparel's Sham Arbitration. Wall Street Journal Law Blog [online], 4 November. Available from:

https://blogs.wsj.com/law/2008/11/04/the-story-behind-american-apparels-shamarbitration/ [Accessed 5 March 2020].

Southworth, A., 2008. Lawyers on the Right: Professionalizing the Conservative Coalition [online]. University of Chicago Press. Available from: https://doi.org/10.7208/chicago/9780226768366.001.0001 [Accessed 5 March 2020].

Steffek, F., et al., eds., 2013. Regulation of Dispute Resolution - ADR and Access to Justice at the Crossroads. Oxford/Portland: Hart.

Sternlight, J., 1996. Panacea or Corporate Tool?: Debunking the Supreme Court's Preference for Binding Arbitration. Washington University Law Quarterly [online], 74(3), 637. Available from:

https://openscholarship.wustl.edu/law lawreview/vol74/iss3/6/ [Accessed 5 March 2020].

Sternlight, J., 2002. Is the U.S. Out on a Limb? Comparing the U.S. Approach to Mandatory Consumer and Employment Arbitration to that of the Rest of the 
World. University of Miami Law Review [online], 56, 831-64. Available from: https://scholars.law.unlv.edu/facpub/273/ [Accessed 5 March 2020].

Sternlight, J., 2004. In Search of the Best Procedure for Enforcing Employment Discrimination Laws: A Comparative Analysis. Tulane Law Review [online], vol. 78, 1401-1499. Available from: https://ssrn.com/abstract=571163 [Accessed 5 March 2020].

Sternlight, J., 2012. Tsunami: ATET Mobility v Concepcion Impedes Access to Justice. Oregon Law Review [online], vol. 90, 703. Available from: https://ssrn.com/abstract=1924365 [Accessed 5 March 2020].

Sternlight, J., 2019. Mandatory Arbitration Stymies Progress Towards Justice in Employment Law: Where to, \#MeToo? Harvard Civil Rights-Civil Liberties Law Review [online], 54, 156-210. Available from:

https://scholars.law.unlv.edu/facpub/1178?utm_source=scholars.law.unlv.edu $\% 2$ Ffacpub\%2F1178 [Accessed 5 March 2020].

Sternlight, J., 2020a. Justice in a Brave New World? Technology, Trials and Dispute Resolution-Moving Beyond Truth to Justice. Connecticut Law Review, 22.

Sternlight, J., 2020b. Pouring A Little Psychological Cold Water on ODR. Journal of Dispute Resolution [online], 2020(1). Available from: https://scholarship.law.missouri.edu/jdr/vol2020/iss1/5/ [Accessed 20 July 2020].

Stevens, A., and Holden, B.A., 1994. How Bigotry Charges Rocked White and Case. Wall Street Journal, 19 August, B-1.

Sturdevant, J.C., 2019. Settlement Agreements: Clauses that Don't Belong and Ethical Considerations [Presentation]. myLawCLE [online], 10 June. Available from: https://mylawcle.com/products/video-broadcasts/settlement-agreements-clausesthat-dont-belong-and-ethical-considerations/ [Accessed 5 March 2020].

Susskind, L., McKearnan, S., and Thomas-Larmer, J., 1999. The Consensus Building Handbook: A Comprehensive Guide to Reaching Agreement [online]. Thousand Oaks: Sage. Available from: http://doi.org/10.4135/9781452231389 [Accessed 5 March 2020].

Szalai, I.S., 2018. The Failure of Legal Ethics to Address the Abuses of Forced Arbitration. Harvard Negotiation Law Review [online], 24, 127-183. Available from: https://ssrn.com/abstract=3447432 [Accessed 5 March 2020].

Tannen, D., 1998. The Argument Culture: Moving from Debate to Dialogue. New York: Random House.

Thompson, A.C., 2002. Courting Disorder: Some Thoughts on Community Courts. Washington University Journal of Law \& Policy [online], 10(1), 63. Available from: https://openscholarship.wustl.edu/law journal law_policy/vol10/iss1/5 [Accessed 5 March 2020].

Tippett, E., 2018. The Legal Implications of the \#Metoo Movement. Minnesota Law Review [online], 103, 229-88. Available from:

https://www.minnesotalawreview.org/wpcontent/uploads/2019/01/12Tippett MLR.pdf [Accessed 5 March 2020]. 
Tippett, E., 2019. Non-disclosure Agreements and the \#MeToo Movement-What do we do now? Dispute Resolution Magazine [online], 25(2-\#MeToo: Special Issue), 12-15. Available from:

https://www.americanbar.org/groups/dispute resolution/publications/dispute re solution magazine/2019/winter-2019-me-too/non-disclosure-agreements-and-themetoo-movement/ [Accessed 5 March 2020].

Tuerkheimer, D., 2019. Beyond \#Metoo. New York University Law Review [online], 94(5), 101-160. Available from: https://www.nyulawreview.org/issues/volume-94number-5/beyond-metoo/ [Accessed 5 March 2020].

Umbreit, M., 1994. When Victim Meets Offender. Monsey: Criminal Justice Press.

West, R., 2011. The Limits of Process. In: J.E. Fleming, ed., Getting to the Rule of Law: NOMOS L [online], 32-51. New York University Press. Available from: https://doi.org/10.18574/nyu/9780814728437.003.0002 [Accessed 5 March 2020].

Wexler, L., 2019. 2018 Symposium Lecture: \#MeToo and Procedural Justice. Richmond Public Interest Law Review, 22(2), 13-23.

Wexler, L., Robbennolt, J., and Murphy, C., 2019. \#MeToo, Times Up and Theories of Justice. University of Illinois Law Review [online], 2019(45). Available from: https://doi.org/10.2139/ssrn.3135442 [Accessed 5 March 2020].

Williams, J.B., Singh, L.O., and Mezey, N., 2019. \#MeToo as Catalyst: A Glimpse into $21^{\text {st }}$ Century Activism. University of Chicago Legal Forum [online], 2019(371). Available from: https://ssrn.com/abstract=3520217 [Accessed 5 March 2020].

Yablon, C.M., 2019. The Lawyer as Accomplice: Cannabis, Uber, Airbnb and the Ethics of Advising Disruptive Businesses, Minnesota Law Review / Cardozo Legal Studies [online], Research Paper №. 580. Available from:

https://ssrn.com/abstract=3389559 [Accessed 5 March 2020].

Zimmer, M.B., 2019. Judges and Courts Respond to Opioid Litigation Engulfing U.S. Court Systems. International Journal for Court Administration [online], 10(1), 5-11. Available from: https://doi.org/10.18352/ijca.290 [Accessed 5 March 2020].

\section{Cases cited}

American Express v Italian Colors Restaurant, 570 U.S. 228 (2013).

ATET Mobility v Concepcion, 563 U.S. 333 (2011).

BMW of North America v Gore, 517 U.S. 559 (1996).

Circuit City Stores, Inc. v Adams 532 U.S. 105 (2001).

Dept. of Commerce v New York, 588 U.S. -(2019)

E. Bay Sanctuary Covenant v Barr, -F. Supp. 3 2019 WL 3323095 (N.D. Cal. 2019).

Epic Sys. Corp. v Lewis 138 S. Ct. 1612 (2018). 584 U.S. (2018).

Gilmer v Interstate/Johnson Lane Corp. 500 U.S. 20 (1991).

Hawaii v Trump, 878 F. $3^{\text {rd }} 662$ (9 $9^{\text {th }}$ Cir. 2017). 
Juliana $v$ United States, complaint available from:

http://blogs2.law.columbia.edu/climate-chang-litigation/wpcontent/uploads/sites/11.case-documents/2015/200150910 docket-615-cv1517 complaint.pdf

Latif v Morgan Stanley and Co. (S.D. NY. 18 cv11528, June 26, 2019).

Liebeck v McDonalds, 1995 WL 360309 (Dist. Ct. N. Mexico).

Macfarlane v Canadian Universities Reciprocal Insurance Exchange, Ontario Superior Court of Justice, CV 19-00619449-0000, ONSC 4631 (August 2, 1019).

Mitsubishi v Solar Chrysler-Plymouth 473 U.S. 614 (1988).

Nelson v American Apparel, Inc., B205937, Court of Appeal, California, 2nd Dist. Oct. 28, 2008 (depublished by California Rule of Court 8.1115(a).

Wal-Mart v Dukes 564 U.S. 338 (2011). 